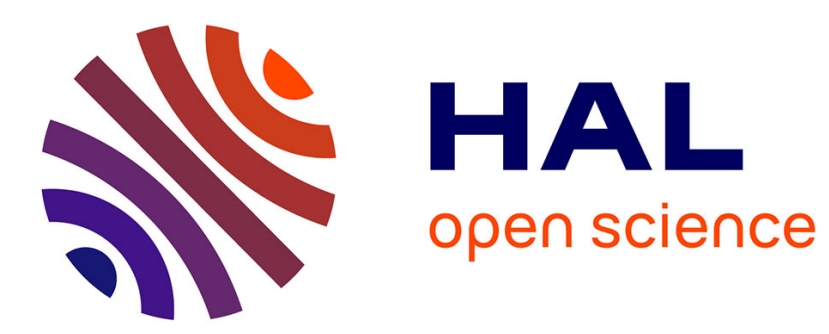

\title{
Mirror and canonical neurons are not constitutive of aesthetic responses
}

Roberto Casati, Alessandro Pignocchi

\section{To cite this version:}

Roberto Casati, Alessandro Pignocchi. Mirror and canonical neurons are not constitutive of aesthetic responses. Trends in Cognitive Sciences, 2007, 11, 10, pp.410. 10.1016/j.tics.2007.07.007 . ijn_00171310

\section{HAL Id: ijn_00171310 \\ https://hal.science/ijn_00171310}

Submitted on 12 Sep 2007

HAL is a multi-disciplinary open access archive for the deposit and dissemination of scientific research documents, whether they are published or not. The documents may come from teaching and research institutions in France or abroad, or from public or private research centers.
L'archive ouverte pluridisciplinaire HAL, est destinée au dépôt et à la diffusion de documents scientifiques de niveau recherche, publiés ou non, émanant des établissements d'enseignement et de recherche français ou étrangers, des laboratoires publics ou privés. 


\title{
Mirror and canonical neurons are not constitutive of aesthetic responses
}

\author{
Roberto Casati ${ }^{1,2}$ and Alessandro Pignocchi ${ }^{1}$ \\ ${ }^{1}$ Institut Jean Nicod, CNRS ENS-DEC EHESS, Pavillon Jardin, 29 rue d'Ulm, 75005 Paris, France \\ ${ }^{2}$ IUAV University, Dorsoduro 2206, Venice, Italy \\ Corresponding author: Casati, R. (roberto.casati@ens.fr).
}

The alleged neural basis of empathic responses to artworks is only of marginal relevance for aesthetics and for cognitive theories of art, contrary to Gallese and Freedberg [1].

The activity of the mirror neuron system (MNS) has been claimed to provide the neural underpinnings for several mental capacities, including, but not limited to, imitation, mindreading, language understanding and concept formation. According to Gallese and Freedberg [1], MNS or so-called 'canonical' neurons (or both) are crucially involved in our aesthetic appreciation as well. The claim concerns both the representational content and the vehicle of artworks. There are empathic responses to the representational content of artworks in which actions, objects and sensory interactions (e.g. human bodies being touched or wounded) are displayed; and responses to vehicles (e.g. paint on canvas, sculpted surfaces) in which the gestures of artists are readable from the traces they left (e.g. brushwork). The idea is presented as a major step forward in a landscape of aesthetic studies where the only cognitively relevant aspects of art are 'disembodied' ones, and as new support for neglected or forgotten studies in which empathic or bodily effects were taken to have a major role in aesthetic appreciation.

The proposal is, however, open to the charge of irrelevance to the issues of aesthetic experience and of what constitutes artworks. Already the choice of artworks to be discussed, such as the Michelangelo, Goya, Caravaggio and Pollock quoted in ref. [1], is open to objection: all the works are both famous, so as to suggest and emphasize the importance of this issue for art; and mostly gory, so as better to nail the empathic point. Moreover, the examples are not used specifically. In the case of empathic responses to content, witnessing the corresponding nonartistic real-life scenes, say, of a man trying to escape from a mould of clay, of genital mutilation or of a finger probing an open wound, is expected to arouse relevantly similar responses as those provoked by the artistic examples. In the case of somatic responses to the vehicle, the perception of nonartistic handwriting (itself mentioned in ref. [1]) is documented to have the requested somatic effects that are so telling in the Pollock and Fontana examples. Activation of MNS or of canonical neurons is thus not sufficient for aesthetic appraisal or judgments that something is an artwork. Nor is such activation necessary. Purely conceptual artworks are unlikely to activate the requested motor responses; but artworks they are, and we can appraise them aesthetically.

Two comments:

(i) The question that is relevant to a theory of art is whether empathic response is constitutive of aesthetic response tout court. This is clearly an issue to be addressed before, and independently of, establishing the possible neural underpinnings of empathic response.

(ii) In the case of responses to the vehicle, a promising avenue is open to empathic accounts, considering the nonmarginal corpus of drawings (see Box) and calligraphy in the whole of artistic production (as opposed to the relative marginality of Pollocks and Fontanas).

References

1 Gallese, V. and Freedberg, D. (2007) Motion, emotion and empathy in esthetic experience. Trends Cogn. Sci. 11, 197-203 2 Gombrich, E.H. (1969) Art and Illusion: A Study in the Psychology of Pictorial Representation (2nd edn), Princeton University Press

3 Freyd, J.J (1983) Representing the dynamics of a static form. Mem. Cognit. 11, 342-346

4 Calvo-Merino, B. et al. (2006) Seeing or doing? Influence of visual and motor familiarity in action observation. Curr. Biol. 16, 1905-1910 
Box 1. Style production and recognition as a viable mid-level hypothesis in the cognitive study of art

Still missing from the open field of the cognitive study of art are mid-level hypotheses that are both aesthetically specific (as opposed to general claims, e.g. about emotions) and functionally interfaced with psychological findings. Consider the notion of 'drawing style', central to art history and the philosophy of art. One crucial issue is whether the style of a draughtsman is inherited from other draughtsmen (see ref. [2] for a positive answer). Activation of the MNS might enable the observer of a drawing to retrieve some dynamic components of the gesture of the draughtsman. This in turn might influence the drawing acts of the observer (see ref. [3] for an experiment showing that the direction of the drawing movement can be recovered when perceiving a line). A productive mid-level hypothesis would be that drawing style relies on the dynamics of the hand of the draughtsman and that MNS subserves both style inheritance and recognition, by observers, of such influence between draughtsmen. This claim generates both new distinctions relevant for the philosophy of art and testable hypotheses for neuropsychology. One of them is that experience in drawing production improves the ability to detect influences between draughtsmen (see ref. [4] for related work on dancers). 